值为 2.000), 且信号强度随反应时间规律 性地变 化. 这表明在 $\left(\mathrm{C}_{2} \mathrm{ZrH}_{2}\right)_{\mathrm{x}}$ 与 RNCS 反应的过程中 $\mathrm{Zr}-\mathrm{H}$ 键发生均裂, 反应经过自由基机理进行. 这 种在锆氢化物与不饱和化合物的反应中, $\mathrm{Zr}-\mathrm{H}$ 键
发生均裂的有趣现象文献中还未见报道.

王 梅 贝浼智 郭和夫 (中国科学院大连化学物理研究所)

\title{
沁水煤田北缘晚石炭世火山诱积碳酸盐岩的 发现及成因初探
}

在沁水煤田北缘阳泉荫营一带, 发现一种特殊 类型的碳酸盐岩,它产于太原组四节石灰岩 $\left(K_{2}\right)$ 和 钱石灰岩 $\left(\mathrm{K}_{3}\right)$ 之间,厚 $1-3 \mathrm{~m}$ ，呈透镜状或似层状 夹于 13" 煤层底板砂岩中,貌似细砂岩. 经详细研 究, 应为“火山诱积碳酸盐岩”。在剖面上与凝灰岩 或层凝灰岩共生.

显微镜下,该岩石主由 $0.2-0.5 \mathrm{~mm}$ 的微晶方 解石“凝块”组成，含量大于 $80 \%$ ，“凝块”之间为亮 晶方解石充填，含量小于 $20 \%$ 。“凝块”常呈不规则 同心圆状或皮壳状，其核心多为火山碎屑物质所占 据. 经详细鉴定,这些火山碎屑物质主由玻屑、晶屑 和岩屑组成,占全部岩石的 $25-35 \%$ ．玻首常脱玻 化; 晶屑主为斜长石, 聚片双晶清楚; 岩屑主为安山 岩和安山玢岩岩屑; 晶屑和岩屑中斜长石为 An2530 中性斜长石, 其有序度为 $0.3-0.5$, 属高温斜长 石.

该岩石中不溶残渣的化学全分析结果相当于流 纹岩质和安山岩质凝灰岩, 用各种岩石化学方法㤆 复原岩的数据均落于岩浆岩区.

该岩石中粘土矿物主为水云母及少量蒙 脱 石, 表明 “火山诱积碳酸盐岩”形成于中性至弱碱性 环 境.

该岩石中氧、碳同位素比值为:

$$
\begin{aligned}
& \delta \mathrm{C}_{\mathrm{PDB}}^{13}=-1.19-+0.15 \%, \\
& \delta \mathrm{O}_{\mathrm{PDB}}^{18}=-13.13-14.09 \%,
\end{aligned}
$$

与海相石灰岩 $\left(K_{2}, K_{3}\right)$ 的比值相似，表明“火山诱 积碳酸盐岩”形成于咸水或半咸水环境.
该岩石中微量元素比值, 为 $\mathrm{B} / \mathrm{Ga}, \mathrm{Sr} / \mathrm{Ba}, \mathrm{V} / \mathrm{Zr}$, 与海相泥岩比值十分相近, 而高于陆相泥岩, 也说明 “火山诱积碳酸盐岩”形成于接近海相的咸水或半咸 水环境。

通过对本区沉积环境的分析，该岩石应形成于 与海水局部相通的三角洲分流间湾或坝后泻湖的咸 水或半咸水环境，而且当时曾伴随着强烈的火山喷 发，这恰与对该岩石所做的岩石学、矿物学、岩石化 学及氧、碳同位素的研究完全吻合.

根据 Schmalz 和 Chave (1963) 对百慕大海域 和其它海域所取海水样品的分析, 均证明海水对 $\mathrm{CaCO}_{3}$ 来说是饱和的或过饱和的; 同时根据 W. v. Engelhardt (1977) 的热力学计算, $\mathrm{CaCO}_{3}$ 的溶解度 随水温的升高而降低. 所以，碳酸盐的沉淀只需水 温的稍许提高. 由此可见，在本区强烈火山作用的 影响下,除部分火山灰形成凝灰岩或层凝灰岩外，还 有大量火山灰尘，在炽热状态下沉降于三角洲分流 间湾或坝后泻湖中,由于水温的急剧开高,使 $\mathrm{CaCO}_{3}$, 过饱和,由水中析出的微晶方解石, 围绕火山灰尘形 成大量的碳酸盐“凝块”而发生聚沉，从而形成本区 首次发现的“火山诱积碳酸盐岩”。

“火山诱积碳酸盐岩”的发现, 为碳酸盐的研究 提供了一个新的研究领域, 也为本区晚石炭世火山 活动提供了一个重要的信息.

$$
\begin{gathered}
\text { 贾 炳 文 } \\
\text { (山西矿业学院,太原) }
\end{gathered}
$$

\section{浙江长兴二叠、三叠纪之间的冲击事件}

我们最近对浙江长兴 $\mathrm{P}-\mathrm{T}$ 界线剖面进行了较 详细的研究，发现在界线及其附近有冲击事件发生 的记录.
1. 长兴阶上部灰岩(界线以下 $30 \mathrm{~m}$ 以内)中沉 积构造具有明显的同沉积变形。灰岩分层断面呈明 显的细经化和局部增厚, 分层内部层理随同分层发 